\title{
A methodological framework to assess the socio- economic impact of underground quarries: a case study from Belgian Limburg
}

\author{
Sergeant, A. ${ }^{1}$, Poesen, ${ }^{1}$, Duchateau, P. ${ }^{2}$, Vranken, L. $^{1}$ \\ ${ }^{1}$ KU Leuven, Department of Earth and Environmental Sciences, Celestijnenlaan 200 E, 3001 Leuven, Belgium \\ 2 Service for Quarries, Riemst, Belgium \\ Corresponding author: Liesbet.Vranken@ees.kuleuven.be
}

This document is a postprint version.

The published version can be found at

http://www.sciencedirect.com/science/article/pii/S0048969715307397

(doi:10.1016/i.scitotenv.2015.09.079)

\begin{abstract}
This study developed a methodology to assess the socio-economic impact of the presence and collapse of underground limestone quarries. For this we rely on case study evidence from Riemst, a village located in Eastern Belgium and use both secondary and primary data sources. A sinkhole inventory as well as data about the prevention costs provided by the municipality was used. To estimate the recreational values of the quarries, visitor data was obtained from the tourist office of Riemst. Next, two surveys were conducted among inhabitants and four real estate agents and one notary. The direct and indirect damages were assessed using respectively the repair cost and production and real estate value losses. The total yearly direct and indirect damage equals $€ 415000$ ( $\pm € 85000$ ) and more than half of it can be attributed to the depreciation of real estate ( $€ 230000)$. The quarries have recreational, cultural-historical and ecological values and thus generate societal benefits. The yearly recreational value was at least €613 000 in 2012 values. The ecological and cultural-historical values augment to $€ 180000$ per year (in 2012 values). Further, our study indicates that the gains from filling up the quarries below the houses located above an underground limestone quarry outweigh the costs in the case study area. The net gain from filling up the underground quarry ranges $€ 38700$ to $€ 101700$ per house. This is only a lower bound of the net gain from filling up these underground quarries since preventive filling makes future collapses less likely so that future direct repair costs will be most likely smaller.
\end{abstract}

Key-words: Sinkholes, Direct and Indirect Damage, Societal Benefits, Ecological Value, Recreational Value 


\title{
A methodological framework to assess the socio- economic impact of underground quarries: a case study from Belgian Limburg
}

\author{
Sergeant, A., Poesen, J., Duchateau, P., Vranken, L.
}

\section{Introduction}

Worldwide, quarry activities lead to anthropogenic cavities. Due to anthropogenic and natural factors, sinkholes may form above these cavities (e.g. Parise, 2012; Van Den Eeckhaut et al., 2007). Sinkholes in general cause considerable damage to people, infrastructure and agricultural land and hereby induce costs, including direct costs to private and public property, indirect costs and intangible costs (e.g. Gutiérrez et al., 2014; Parise and Lollino, 2011; Sahu and Lokhande, 2015; Van Den Eeckhaut et al., 2007). For example in the case a house is affected by a sinkhole, direct losses refer to the costs of repairing or reconstructing the house and the injuries or fatalities caused by the collapse. Indirect damage includes the real estate value loss. In the case agricultural land is affected, direct damage refers to loss of agricultural output, while indirect damage may include decline of future productivity (output per hectare) due to the sinkhole formation. Not only sinkhole formation may lead to economic losses. The mere presence of underground quarries and the hazard of sinkhole formation, may already result in economic losses, particularly indirect damage due to real estate value losses.

Sinkhole risk can be reduced by limiting or prohibiting development in the most hazardous areas based on sinkhole susceptibility and hazard maps (e.g. Buttrick et al., 2001; Paukstys et al., 1999). However, this is not always a suitable strategy due to an increases in human population which leads people to occupy more hazardous areas (e.g. Buttrick et al., 2011; Parise et al., 2009). Therefore, it may be more desirable and feasible to take corrective measures aimed at diminishing the formation of sinkholes or non-structural measures aimed at reducing or ameliorating the financial losses and harm to people (e.g. Gutiérrez et al., 2014; Jones and Blom 2014; Zhou and Beck 2011). To identify optimum mitigation strategies a cost-benefit analysis (CBA) needs to be made (Galve et al., 2012a). To assess potential losses, an assessment of the spatial and temporal probability of sinkhole formation is needed, as well as an assessment of the vulnerability of the elements at risk and an analysis of socio-economic sinkhole-related consequences. While sinkhole susceptibility and hazard studies are becoming more common (Argentieri et al., 2015; Galve et al., 2008; Guerrero et al., 2008; Ozdemir, 2015; Samyn et al., 2014; Taheri et al., 2015), few studies have concentrated on quantitatively analysing the socioeconomic consequences of these features.

In a CBA, one compares the losses in a "without mitigation" scenario with the cost in the "with mitigation" scenario. The costs in the "with mitigation scenario" include the expenditures on mitigation plus the direct and indirect damage caused by sinkholes that cannot be prevented with the applied measures (residual risk). The benefits in the "with mitigation" scenario encompass the saved losses due to mitigation (Galve eta al. 2012a, b) as well as the ecological and cultural benefits related to underground quarry stabilization measures. As such, a proper sinkhole-related damage assessment is needed to perform a CBA of mitigation measures. While a proper assessment of all sinkhole-related 
damage is needed, the losses - and particularly the indirect losses- are often difficult to identify and/or assess (Gutiérrez et al., 2014). As a consequence, many studies focus on qualitative or semiquantitative damage assessments or focus only on one type of damage - typically direct damage (e.g. Sahu and Lokhande; 2015).

Therefore, the main goal of this study was to assess the socio-economic impact of the underground limestone quarries. In particular, we aim to develop a methodology to assess different types of sinkhole-related consequences. Previous studies indicated that mass movements such as landslides and sinkhole collapses have led to different types of damage (Markantonis et al., 2012; PapathomaKöhle et al., 2015; Zêzere et al., 2008). Therefore, different types of data and methodologies were used to assess quantitatively their economic impact. Both direct as well as indirect damage is considered as well societal benefits linked to corrective measures aimed at diminishing the formation of sinkholes or non-structural measures aimed at reducing or ameliorating the financial losses and harm to people. All damage and benefits are expressed in monetary values as it allows to compare all different types of costs and benefits. For this we rely on different valuation techniques, ranging from direct valuation approaches (cost-based and production function based approaches) to stated and revealed preferences approaches. The methodology is developed for a case study area in Belgium. However, this area stands as an example for many regions around the globe that are susceptible to sinkhole formation due to underground excavations. As such the methodology developed in this paper can be widely applied elsewhere.

The case study region is located in Eastern Belgium. Since Roman times, calcarenite limestone deposits have been exploited, first by opencast quarrying and later on by underground quarries in Eastern Belgium and South Eastern parts of the Netherlands (Medaerts, 2008). These limestone deposits are found at shallow depth and appeared to be an excellent building stone (Dusar et al 2006). However, due to a combination of natural and anthropogenic factors, some quarries became unstable throughout time. This has led to the collapse of underground quarries with the formation of sinkholes as a consequence.

As the sinkhole-related costs have never been assessed in Belgium, this study aims to estimate the socio-economic consequences related to underground quarry collapses. For this we rely on case study evidence from the village "Riemst" located in Eastern Belgium. By 1958, around 200 ha was excavated in Riemst (Medaerts, 1998). The first documented sinkhole formation can be dated back to 1792 (Van Den Eeckhaut et al., 2007). One of the largest collapses took place on December 23, 1958 when the Roosburg quarry collapsed. At that time, several mushroom growers were working in the quarry and unfortunately this collapse caused the demise of 18 people. At least 3-4 ha of land was significantly deformed by subsidence or cracks caused by this collapse. After this event it was no longer allowed to grow mushrooms in the underground quarries and the extraction of calcarenite limestone shifted to an aboveground production (Medaerts, 1998). In the following years, new sinkholes formed which affected different types of elements (Figure 1).

To quantify the socio-economic impact due to presence of underdround limestone quarries in Riemst, this study will assess (i) the direct, indirect and intangible damage, which includes a qualitative description of psychological damage due to the collapses, (ii) the forgone benefits in terms of 
recreational, cultural-historical and ecological values and (iii) the net benefits of possible preventive measures to limit future damage.

\section{Study area}

\subsection{Location and characteristics}

The municipality of Riemst $\left(58 \mathrm{~km}^{2}\right.$ ) (Figure $2 \mathrm{~A}$ ) consists of eleven boroughs/villages and lies in the South Eastern part of Belgian Limburg. Although other underground calcarenite limestone quarries can be found in the neighbouring municipality 'Heers' and in the Netherlands, this study focuses solely on Riemst because most (reported) sinkholes occurred in this municipality. Moreover, the quarries in Riemst are mainly located below residential areas which lead to high socio-economic damage when a quarry collapses (Van Den Eeckhaut et al., 2007). Figure 2B, C and D show for Kanne, Val-Meer and Zichen-Zussen-Bolder respectively (i.e. the three boroughs of Riemst where most calcarenite extraction has taken place) the extent of the quarries. The total excavated area is 200ha, which corresponds to $3.45 \%$ of the surface area of Riemst, and the total length of the passages is ca. $400 \mathrm{~km}$ (Medaerts, 1998).

Riemst has a maritime temperate climate with an annual mean air temperature of $9.8^{\circ} \mathrm{C}$ (Van Den Eeckhaut et al, 2007) and a mean annual rainfall of $764.7 \mathrm{~mm}$ as recorded in Maastricht, the most nearby measuring station (1983-2012; KNMI, Maastricht). Riemst has dry loamy soils because of the permeable chalk layers and the relative large depth to the water table (Dusar, 2005). The lithology consists of a Quaternary overburden and limestone caclcarinite at shallow depth (Romein, 1976). The formation of Maastricht was deposited in the Upper Cretaceous period and has a remarkably high pureness (up to $98 \% \mathrm{CaCO}_{3}$ ) (Natuurhistorisch Museum, 1981) and a porosity of $50 \%$, which gives it high isolating properties. Because of the high pureness, high porosity and few flint nodules in this formation, it was very suitable to be used in construction (Gullentops and Wouters, 1996). Riemst is a rural municipality and most land is cropland with some pastures near the village centres (OC-GIS Vlaanderen, 2013).

\subsection{History of quarries in Riemst}

The excavation of the Maastricht formation dates back to the Roman period, at first it was surface mining, but since medieval times subsurface quarrying occurred. The oldest year found on the wall paintings in the quarries is 1468 . The excavations were initially mostly small scale, but became large scale later on. From the $20^{\text {th }}$ century onwards, the excavations were no longer economically profitable. However, because of the constant air temperature $\left(11^{\circ} \mathrm{C}\right)$ and high humidity $(>90 \%)$, the quarries were ideal for growing mushrooms. Between the beginning of the $20^{\text {th }}$ century and 1958 , the mushroom production in the quarries was one of the most important production sites in Western Europe. This ended in 1958, when a large collapse took place, causing the demise of 18 people. After that date, the underground large-scale production of mushrooms was forbidden (Medaerts, 1998). Due to the tranquillity, the constant air temperature and high humidity, the quarries are an ideal hibernation spot for bats. By closing the entrances of most quarries for humans 20-30 years ago, the bat population grew significantly since tranquillity is a crucial factor (Bosch et al., 1978). The quarries also have many 
wall paintings which were made by excavators, people who sought shelter during war times, playing children and owners of the quarries (Medaerts, 1998).

\subsection{Causal factors for collapses of underground quarries}

The main disadvantage of the quarries is the risk of collapse, which happened several times in the past. The first documented sinkhole formation dates back to 1792. Since then, the formation of 151 sinkholes are recorded in Riemst (Duchateau, 2013). The causal factors for these sinkholes can be divided into natural and anthropogenic factors. The main natural factors are meteorological conditions (high rainfall, snowmelt), high groundwater table, long-term deterioration of the quarry caused by creep, enlargement of cracks in the roof beds by roots and sagging of roof beds. The main anthropogenic factors include overloading of the quarry roof, concentrating water above quarries, incorrect exploitation which results in unstable structures and pillar robbing e.g. for better accessibility with tractors and other vehicles (Van Den Eeckhaut et al., 2007).

\section{Materials and methods}

\subsection{Data collection}

For this research both secondary and primary data sources were used. A sinkhole inventory provided by the municipality was used as well as data about the prevention costs made by the municipality. To estimate the recreational values of the quarries, visitor data was obtained from the tourist office of Riemst. Next, two surveys were conducted: one with 28 inhabitants and another with four real estate agents and one notary.

The sinkhole inventory, provided by the municipality of Riemst, consists of newspaper articles, collapse reports made by the municipality, cadastral maps and journal articles. A first inventory was made for the period 1792 - 2003 (Van Den Eeckhout et al., 2007), but was updated until 2012 in this research. This inventory was used to create a database in which the sinkholes were listed with their dimensions and a description of the damage caused by the sinkhole. These damage descriptions were later on used to estimate the direct costs related to these sinkholes.

The municipality of Riemst also provided information about the costs they made to prevent quarry collapses. These costs include a measuring system to monitor the stability in the public quarries, the costs made to fill up certain quarries below public roads, the wage cost of the quarry manager of Riemst and a (working) fee for volunteers who monitor the stability of the quarries on a regular basis.

The tourist office of Riemst provided data on 4131 visitors of the public quarries in 2012. Data on the place of origin of these visitors (at municipality level) and the number of visitors was used for the analysis. In total, 24000 people visited the quarries in 2012. It was assumed that the obtained visitor data was a representative sample $(n=4131)$ of all the visitors $(N=24000)$ and could therefore be extrapolated to assess the recreational value of the quarries in Riemst.

Additional data was collected through a survey with 28 inhabitants living in areas above or nearby a quarry in Riemst. Of these inhabitants, 16 persons (57\%) actually live above an underground quarry and 12 persons (43\%) live nearby one. The interviewees were partly chosen randomly and partly by 
recommendation of either other inhabitants or either the town quarry supervisor. The survey was made to complete the sinkhole inventory, to assess psychological damage due to sinkhole formations and to assess the ecological and cultural value of the quarries. In addition, to determine direct damage, the inhabitants were asked if they had suffered damage to their property due to the formation of a sinkhole and if so, if they could describe and quantify the damage. They were also asked to describe damage caused by sinkholes in their neighbourhood. The psychological damage was assessed by asking about their fear of damage to their property and whether they have health problems caused by stress related to the potential formation of sinkholes. The ecological and cultural values of the quarries were assessed by asking willingness to pay questions in the survey (see further).

Another survey was conducted among four real estate agents and one notary to assess the impact of the calcarenite limestone quarries on real estate prices. More specifically, the interviewees were asked to value (i.e. give an estimation of the sales price of) a hypothetical house typical for the region which is (1) located above a filled quarry, (2) located above an unfilled quarry and on a parcel where no sinkhole has occurred in the past, (3) located above an unfilled quarry and on a parcel where a sinkhole has been formed in the past, and (4) not located above a quarry.

Key figures about the repair costs of for example roads, public utilities and construction work in Flanders were taken from Vranken et al. (2013). All costs reported in this study refer to the cost in 2012.

\subsection{Methods}

\subsection{1 (In)direct damage}

The direct costs related to quarry collapses can be divided into a cost to fill up the sinkhole (filling cost) and a cost to repair sinkhole-induced damage to private and public properties (repair cost). The filling cost is determined by the volume of the collapse. A sinkhole formed under roads and houses needs more stable filling material and will cost $€ 50 / \mathrm{m}^{3}$ in 2012 (Duchateau, 2013). If, on the other hand, the sinkhole is formed under cropland, pasture or forest, the filling cost will be between $€ 1 / \mathrm{m}^{3}$ and $€ 4.5$ $/ \mathrm{m}^{3}$ (bodemrichtlijn.nl, 2013). These prices include the price of the filling material, transport and deposit of the material. In some cases, when only the area of the collapse was known, the volume and thus the filling cost was calculated using the average depth of other collapses.

The repair cost is estimated using the substitution method. The repair cost could be calculated based on the damage descriptions in the sinkhole inventory and key cost figures reported by Vranken et al. (2013) or collected from building companies. A distinction between private and public properties was made. Private property includes damage to buildings (private and industrial), gardens and appurtenances e.g. damage to fences, driveways and stables. The reseeding of pasture after filling up a sinkhole is also considered to be a direct cost. Between 1926 and 2012, five houses were completely destroyed by sinkhole formations. In these cases, instead of a repair cost, the average housing price in Riemst, i.e. $€ 215000$ in 2012, was assigned as cost. Damage to public property includes damage to roads, recreational areas and utility lines, which includes water mains, electricity and sewage. If a sinkhole forms below a road, the road has to be completely reconstructed after the sinkhole has been filled in. Table 1shows the unit prices for damage to utility lines used in this study. 
In the period 1665-2013 a total of 38 casualties have been reported in Riemst (Van Den Eeckhout et al., 2007) due to underground quarry collapse. Loss of life is also an important direct impact of collapses. However, we did not want to put a value on a human life and therefore we decided to focus on economic damage and not to include the loss of lives in our assessment.

The estimated indirect costs include the devaluation of real estate, the production losses and the prevention costs. It was not possible to use the hedonic pricing method (Perman et al., 2011) for the estimation of the devaluation of real estate because the lack of sufficient data. Therefore, the devaluation of real estate was assessed by carrying out a survey with four real estate agents and one notary. To improve the reliability, the real estate agents were chosen not only in the municipality of Riemst, but also in the neighbouring municipalities of Tongeren and Bilzen. Notaries and real estate agents are involved in many transfers of properties. Based on the numerous sales they have witnessed, they can provide an average decrease in real estate value due to a house's location above a quarry without releasing any personal information about the seller or buyer. Only few real estate agents and one notary have been interviewed, but since their estimates are based on several property transfers in the study region, this seems justified. They were asked to make an estimation of the value loss due to the presence of the underground limestone quarries based on three scenarios (see Table 2). These scenarios are compared with a reference house, being a hypothetical house typical for the region and not located above a quarry. The value of this reference house is compared with scenario 1 , where a similar house is located above a quarry that has been filled up completely, scenario 2 , where the house is located above a quarry that has not been filled up but where there has never been a sinkhole on the property, and with scenario 3 , where the house is located above a quarry that has not been filled up and where a sinkhole formed on the property in the past. The number of houses in the affected areas were counted based on cadastral maps and Google Street View. By multiplying the average decrease in price, the average house price, which was $€ 215000$ in 2012 (Trends, 2012), and the number of affected houses, the total devaluation in real estate can be assessed.

The production losses are determined by the land rental price and lost crop yields. The unit rental price is $€ 0.0268 / \mathrm{m}^{2}$ for agricultural land and $€ 0.026 / \mathrm{m}^{2}$ for pasture (Statbel rent prices, 2012). By multiplying the unit rental price with the sinkhole area, the total loss in rent price can be assessed. However, on agricultural land the crop losses should also be taken into account. For maize, sugar beet, wheat and barley, the main agricultural crops in the region, the average value of the yield is $€ 0.2$ per $^{2}$ in 2012 (Schrevens, 2012). Hence, if a sinkhole occurs in agricultural land, the total production loss will equal $€ 0.2 / \mathrm{m}^{2}$.

Lastly, there are indirect costs originating from three types of prevention measures taken by the municipality of Riemst. Firstly, the most unstable quarries under public roads have been filled up between 1969 and 2009. Secondly, the public quarries in the borough of Kanne were monitored displacements of quarry walls with 69 analogue gauges between 2000 and 2007. These were replaced in 2011 by 13 digital gauges. Third, a quarry manager is permanently hired to monitor the stability of the quarries and to manage prevention and mitigation measures. The cost of this quarry manager is assessed using the average wage of a civil officer and the average number of working days. Moreover, the municipality has six volunteers who alternately monitor the stability of the quarries on a weekly basis by walking around in the quarries and looking for abnormalities. Even though they are volunteers, they receive a compensation for the materials they use, a working fee. In contrast to the preventive 
filling, the measuring systems and the agricultural production losses, which are onetime costs, the wage of the quarry manager and working fee of the volunteers are yearly costs.

\subsubsection{Societal benefits}

The quarries generate several benefits, which will be lost when a sinkhole forms. For example, in the past, many wall paintings have been made so that the quarries have a cultural-historical value. Moreover, the quarries are an excellent hibernation spot for bats and other animal species like the cave spider. Lastly, the quarries generate recreational benefits. Recreation is a source of income for the municipality since the public quarries attract ca. 24000 visitors per year (Beerts, 2012). The cultural-historical, ecological and recreational value of the quarries is assessed so that an estimation of the lost benefits due to a collapse can be made.

The cultural-historical and ecological values are assessed by carrying out a contingent valuation analysis. People were asked about their willingness to pay for a hypothetical situation in which the probabilities of sinkhole formation would be reduced to zero so that the wall paintings and hibernation spots for bats would be preserved. People could indicate on a payment card with a range of $€ 0$ - €20 how much they wanted to pay for the hypothetical situation to occur. They could choose between a one-time or yearly donation. If they choose a one-time donation, the indicated amount was divided by 80, the average human life expectancy in Belgium, to obtain a yearly amount. An average yearly willingness to pay to preserve the cultural-historical and ecological value of the quarries was then calculated. To obtain the total cultural-historical and ecological values, the average willingness to pay was multiplied by the number of inhabitants within the municipality. This will probably be an underestimation of the true value since people from outside of the municipality also might be willing to pay for the preservation of underground quarries.

The recreational value was assessed using the travel cost method. This method establishes a relation between the number of visitors and the travel costs they make to get to the quarries. The Tourist Office of Riemst provided data on 4131 visitors of whom 4001 Belgian and 130 foreign visitors. It was assumed that the sample was representative for the 24000 tourists who visit the quarries annually so the data was extrapolated to 24000 tourists of which 23245 Belgians. The zonal travel cost method is the most suitable since most visitors visit the quarries only once a year or less. Belgium was divided into nine circular zones around the municipality of Riemst(Figure ). For each zone, the visitor rate, being the number of visitor coming from that zone over the total number of visitors, was calculated and the following trip generating function was assumed:

$v_{i}=\alpha+\beta\left(T_{1}+P\right)+\varepsilon_{i}$

with $v_{i}$ the visitor rate (in \%) of zone $i, \alpha$ and $\beta$ parameters to be estimated, $T_{i}$ the travel costs (in $€$ ) from zone $i, \mathrm{P}$ the admission price (in $€$ ) and $\varepsilon_{\mathrm{i}}$ an error term, which is assumed to be zero. The admission price varies between $€ 4$ and $€ 5.5$, depending on the visited public quarry. It is assumed that both quarries attract the same amount of people, each 12000 per year, so the average admission price becomes $€ 4.75$. The travel cost per kilometre is set on $€ 0.3456$, the official mileage in Belgium (Fedweb, 2012). Based on available data, one can estimate the parameters $\alpha$ and $\beta$. Using equation (1) and the estimated parameters, one can predict visitation rates with different hypothetical 
admission prices. This allows to derive a demand curve for quarry visits as a function of potential admission prices. In particular, multiplying the predicted visitation rate by the zonal population and then summing across all $i$ zones yields for each potential admission price a point on the demand curve. This relation can be graphically presented and the area under the curve and to the right of the admission price equals the consumer surplus which is a proxy for the recreational value of the quarries (Perman et al., 2011).

\subsubsection{Intangible costs}

The intangible costs are the psychological and health effects due to the threat of a quarry collapse. In the survey among inhabitants, the interviewees were asked to point out on a 10 point likert scale whether they fear something will happen to their property due to a sinkhole formation. If so, they were asked if the fear had an effect on their health. Additionally, they were asked if they ever thought about moving due to the presence of the quarries.

\subsubsection{Dealing with uncertainty and calculating 2012 values}

During data collection, it often occurred that different sources gave different damage values for the dimensions of the sinkhole. To make the damage estimations as accurate as possible, minimum and maximum estimations are presented. By using minimum and maximum values, there is a high probability that the impact of the quarry collapse (and related costs) is captured.

The values have all been expressed in 2012 values to deal with general price level changes over time. The year 2012 is used as reference year and all the prices are calculated for or recalculated to 2012 values using the real interest rate. This implies that the nominal interest rate is corrected for inflation so that decreasing purchasing power is accounted for. To calculate 2012 values, the Fisher method is used (see Vranken (2013) for more details). The Fisher method uses the nominal interest rate $(\mathrm{R}, \%)$ and the average inflation $(i, \%)$ to calculate a real interest rate $(r, \%)$ :

$$
1+R=(1+r) *(1+i) \quad \text { so that } \quad r=\frac{1+R}{1+i}-1
$$

The nominal interest rate $(6.86 \%)$ and the average inflation (3.39\%) were calculated by taking the average value for the period 1952-2012 (since the inflation was only available since 1952). Using the Fisher equation, one arrives at a real interest rate of $2.85 \%$. The 2012 value is calculated according to the following equation:

2012 value $=$ value in year $x *(1+\text { real interest rate })^{(2012-x)}$

\section{Results of the socio-economic impact analysis}

\subsection{Sinkhole evolution in Riemst}

The considered period for the socio-economic impact analysis is 1926-2012. Between 1792 and 1926 only 4 sinkholes were reported and for only one of them additional information about the extent of the sinkhole is available. Therefore these sinkholes were not considered in the socio-economic impact 
analysis. Figure 4 shows the annual number of sinkholes for the period $1749-2012(n=151)$. This figure is based on Van Den Eeckhaut et al (2007) who reported sinkholes that occurred before 2003 and is updated until 31-12-2012 (Duchateau, 2013).

\subsection{Assessment of direct and indirect damage}

For a period of 86 years (1926-2012), detailed information about the dimensions of and damage due to sinkholes is known for 96 collapses. These cases were used to calculate the direct and indirect damage. The direct costs, agricultural production losses and prevention costs were rather straightforward to assess based on the dimensions of the sinkhole, a detailed description of the damage and the unit prices which were obtained during the data collection. However, the devaluation of real estate for three scenarios (see Materials and Methods section and Table 2). Depending on the scenario, the decrease in real estate value ranges from $2 \%$ to $56 \%$ for houses located above a quarry. Based on the inventory of underground quarries (Figure 2), houses under scenario 3 could easily be identified. The real estate value loss of these houses amounts to 8 million euro. Unfortunately, based on cadastral maps and Google Street View, one could not make a distinction between houses under scenario 1 , i.e. located above a quarry that has been filled up, and houses under scenario 2, i.e. located above a quarry that has not been filled up but where there has never been a sinkhole on the property. Therefore, we initially assumed that all houses which are located above a quarry and which don't appear in the sinkhole inventory (thus not under scenario 3), were located above a quarry that has been filled up (scenario 1 ) and suffer a real estate value decrease of $2 \%$ relative to the reference situation. Under this assumption, the real estate value loss of houses located above a quarry and not corresponding to scenario 3 , augments to 1.6 million $€$. Together with the real estate value loss of the houses under scenario 3 , this gives a lower estimate of the real estate depreciation of 9.6 million $€$. Next, we assumed that all houses that were located above a quarry and that do not appear in the sinkhole inventory (thus not under scenario 3 ), were located above a quarry that has not been filled up, but that there was never any sinkhole formation on the property (scenario 2). Houses under scenario 2 suffer a decrease in real estate value of $7 \%$. Under this assumption, the real estate value loss of all houses located above a quarry but not under scenario 3, augments to 5.5 million $€$. Together with the real estate loss of houses under scenario 3 , this gives a value loss of 13.6 million $€$. As such, an upper limit of the real estate depreciation is obtained. On average, the total depreciation of real estate in Riemst is €11 617525 (Table 3).

Table 4 shows the results of the damage assessment. Economic damage due to the presence of underground limestone quarries mainly stems from devaluation of real estate. Real estate values losses amount on average to 11.5 million $€$. For the past 86 years, the costs related to filling up sinkholes and preventive filling up quarries augments to around 5.5 million euro $€$. The costs for other types of damage are considerably smaller. The agricultural production losses are by far the smallest. Sinkholes below cropland are probably less reported since farmers often fill up the sinkhole by their own means.

\subsection{Assessment of the societal benefits}

According to the survey, the interviewees were on average willing to pay $€ 3.96$ per person per year to preserve the wall-paintings in the quarries. If one extrapolates the willingness to pay to the rest of the municipality (with 16265 inhabitants in 2012), the total cultural-historical value equals €64 334 per 
year. For presevering bat habitats, there was a different willingness to pay between people who live above a quarry and people who don't. People living above a quarry wanted to pay on average $€ 8.28$ per person per year to preserve the hibernation spot for the bats, while those not living above a quarry wanted to pay $€ 7$ per person. This is probably because the former can observe the bats flying around and eating insects therefore attach more value to conserve their habitats. Based on the number of houses above quarries and the average household size, i.e. 2.48 persons (Statbel households, 2013), we estimated that 1076 people were living above the quarries. By extrapolating the two different willingness to pay values, a total ecological value (for bats only) of €115 228 per year was obtained.

To estimate the recreational value of the quarries, the zonal travel cost method was used. Figure 5 shows the trip-generating function for various potential admission prices to the underground quarries. The consumer surplus from visiting the underground quarries equalled $€ 593824$ in 2012 and reflects the recreational value of the quarries.

Table 5 summarizes the societal benefits related to the presence of the quarries. The table indicates the beneficial values that exist as long as the quarries haven't collapsed. When a quarry collapses, a fraction of these benefits will be lost.

\subsection{Estimation of intangible damage}

The conducted survey revealed that the psychological damage related to the presence of quarries in Riemst is rather small. Figure 7 shows that the inhabitants are aware of the potential danger of the quarries. However, when the inhabitants were asked to indicate how much they fear that something will actually happen to their own property, $82.2 \%$ of the respondents answered that they did not fear this at all. Hence, the psychological damage seems to be limited in general. This can be explained by looking at the reasons why people live close to or above a quarry. Most respondents are born and raised in Riemst and grew up with the quarries and the potential dangers and some of them still live in their parental homes (Figure 7)

\subsection{Assessment of the annual damage and forgone benefits}

To arrive at the annual economic damage due to the presence of limestone quarries, we looked at the direct and indirect damage over a certain period. The direct costs, production losses and preventive filling measures were assessed for a period of 86 years. The working fee for the volunteers as well as the wage of the quarry manager was assessed for a period of 35 years, i.e. for the period that the quarries became the responsibility of the municipalities. The preventive costs related to the installation of a measuring system were assessed for a period of 13 year, i.e. the period since the installation of the first measurement system (2000-2012). However, this cost is depreciated over a period of 11 years, the time between the installation of the first and second measurement system, assuming this is the average lifespan (2000-2010).

It was assumed that for all houses located above a quarry the real estate value decreases during their lifetime, i.e. during the 50 year period that a house is on average owned by one person. Hence, to calculate the annual damage linked to the real estate devaluation, we considered that the total real estate value loss was assessed for a 50 year period. The yearly total damage due to the presence of 
underground limestone quarries amounts to $€ 415266$ (Table 7) and a large part of the damage (45\%) can be attributed to the losses of the real estate values.

The yearly loss of benefits depends on the collapsed volume. Therefore, we first made an estimate of the total volume of the quarries. The total excavated area in Riemst is $200 \mathrm{ha}$ or $2000000 \mathrm{~m}^{2}$ of which the pillars occupy $20 \%$ of this volume (Dusar, 2005). The estimated average height of a quarry is $3.75 \mathrm{~m}$. Hence, the total quarry volume is ca. $6000000 \mathrm{~m}^{3}\left(=2000000 \mathrm{~m}^{2} * 3.75 \mathrm{~m} * 80 \%\right)$. If all quarries would collapse, the loss in cultural-historical values would equal $€ 64334$, while the loss in ecological value would equal $€ 115228$. Hence, the loss in cultural value would be $€ 0.01$ per $\mathrm{m}^{3}$ of quarry volume that collapses and loss in ecological value would be $€ 0.02$ per $\mathrm{m}^{3}$. The average collapsed volume of a sinkhole is $10891 \mathrm{~m}^{3}$. This results in an average loss per sinkhole of $€ 117$ cultural-historical value and $€ 209$ ecological value. In the period 1926-2012, there were on average 1.1 sinkholes per year so that the annual loss in cultural-historical and ecological values is only $€ 126$ and $€ 226$ per year respectively (Table 6).

Only two very stable quarries are open to the public and they are not likely to collapse. A yearly loss of recreational values is thus not expected.

\section{Discussion}

\subsection{How to reduce future damage?}

The yearly damage due to the presence of quarries amounts to ca. $€ 415000$. One might wonder whether it is possible to reduce this damage in the future. Preventive filling would limit the decrease in real estate value loss as well as the direct repair costs. Under public domain, preventive filling of the most unstable quarries has occurred. The quarries located under public domain which are currently not filled, entail a smaller risk because they are rather stable. Under pasture and cropland, costs of preventive filling measures are much higher than the repair costs and production losses after a sinkhole has formed. The repair cost for sinkholes under pastures and cropland amounts to $€ 1-4.5 / \mathrm{m}^{3}$, while preventive filling of the quarry costs between $€ 150-158 / \mathrm{m}^{3}$.

Since more than half of the yearly costs can be attributed to the devaluation of real estate, there are some possibilities to reduce future damage related to quarries under private real estate. House owners can opt for the preventive filling of the quarries located below a house. Of the 434 houses located above a quarry, five houses collapsed between 1926 and 2012. This corresponds to a probability of $0.013 \%$ per year that a house will collapse in Riemst. On average, a house is worth $€ 215$ 000 in Riemst. For houses located above a quarry, the economic annual risk related to the presence of a quarry equals $€ 29$ ( $=€ 215000 * 0.000134$ ). Over the 50 year period that an owner typically owns his/her house, the risk augments to $€ 1450$. Preventive filling of a small quarry of $80 \mathrm{~m}^{3}$ amounts to $€ 12$ 000 . Hence, preventive filling is not economically profitable if one only considers the direct impact and temporal likelihood of a sinkhole formation. However, one should also consider the indirect damage and particularly the real value loss of houses due to its location above a quarry. 
The analysis shows that houses under scenario 3, i.e. houses located above a quarry that has not been filled up and located on a plot on which sinkhole related damage occurred in the past, have a depreciation of $55 \%$ or $€ 118000$ on average. When the underground quarries would be filled, scenario 2 would apply and the real estate value loss of these houses would equal $2 \%$ or $€ 4300$ on average. This means that preventive filling of a house under scenario 3 increases its value with $€ 113700$. This is considerably larger than the cost of preventive filling. The cost of filling a small quarry $\left(80 \mathrm{~m}^{3}\right)$ equals $€ 12000$, while filling a medium-sized quarry $\left(480 \mathrm{~m}^{3}\right.$ ) equals $€ 75000$ (Duchateau, 2013). This clearly shows that preventive filling is economically profitable for houses under scenario 3 if one takes direct and indirect impacts, and particularly real estate value losses, into account.

\subsection{Strengths and limitations of the analysis}

There are several studies that analysed hazards related to underground quarries and the impact of sinkhole subsidence (see e.g. Gutiérrez et al., 2014). However, the focus of these studies differs considerably: some aim to ascertain the existence and the characteristics of cavities; others aim to understand the process of sinkhole formation, others' main goal is to identify factors that triggered sinkhole formation, while others try to assess the temporal and spatial likelihood of sinkhole formation (e.g. Brinkman et al., 2008; Gómez-Ortiz and Martín-Crespo, 2015; Gutiérrez et al., 2008; Parise, 2012; Parise et al., 2015; Zini et al., 2015; ). While such studies are crucial for a sinkhole risk analysis, a true economic valuation of sinkhole-related damage and of the costs (and saved losses) related to prevention and mitigation is also an essential part of any risk analysis which in turn forms the basis for risk reduction efforts and preparedness planning (Holcombe et al., 2012; Lee and Jones, 2004; van Westen et al., 2006). The types of sinkhole-related damage is very diverse (Sakhu and Likhande, 2015) and includes direct, indirect and intangible damage (Galve et al., 2012a). Particularly the latter two types of damage are hard to identify and assess (Gutierrez et al, 2014). Also the benefits of mitigation measures aimed at diminishing the formation of sinkholes, are diverse and include not only saved losses but also ecological and cultural benefits due to the stabilization of underground quarries. The merit of the framework proposed in this study is that it considers different types of elements at risk (infrastructure, houses, agricultural land), aims to assess different types of damage and benefits, and expresses costs and benefits in monetary terms so that aggregation and comparisons among them can be made.

To assess sinkhole related damage and assess the benefits of measures aimed at stabilizing the underground quarries, several economic valuation techniques are used. Direct market valuation approaches (such as the cost-based and production-function based approach) are used to assess the costs of preventive measures and the damage to houses, roads, utility lines, and agricultural land due to sinkhole formation. Further, real estate value losses were determined through a survey among real estate agencies and notaries. Revealed and stated preference approaches were also used to assess respectively the recreational value and ecological value of the underground quarries. By combining these valuation techniques, the proposed framework yields a quantitative assessment of different types of sinkhole-related socio-economic consequences which can form the basis for a true sinkhole risk analysis (i.e. an analysis that combines hazard assessment with a consequence analysis).

The focus of the research was to develop the framework and apply it to a case study area. In particularly, an assessment was made of the socio-economic impact of underground limestone 
quarries in the municipality Riemst in Belgium. While an effort was made to assess all damages and benefits related to the presence of the quarries, the estimates presented in this paper are likely to be lower bounds.

Several indirect costs are not taken into account. This includes for example the maintenance costs of the public underground quarries. Furthermore, every two months, the gas pipes are checked by a sniffer detector to find potential leaks and the water pipes are also closely monitored. Some streets in the municipality are closed for heavy traffic and some bus lines are redirected. Moreover, the municipality organises a coordinated disaster drill to improve the cooperation between the municipality, the fire department, the quarry volunteers and the VZW emergency service quarries. All this comes at a cost, but it is hard to assess all of these. Hence, the annual damage (costs) related to the presence of limestone quarries is very likely to be much larger.

Next, not all benefits could be assessed. The recreational revenues were not assessed and the recreational value was only calculated for Belgian visitors but not for foreign visitors. The ecological and historical value was only assessed for the inhabitants of the municipality while other Belgians might also value the preservation of wall paintings and bat hibernation habitats in the quarry. The high ecological value of the quarries is confirmed by the investments made by the BatAction program of the Flemish Government. This program deals with the protection of valuable hibernation spots for bats. They buy and manage strategic areas in Flanders. Within Riemst they manage already more than 7 ha of land, including many areas above the quarries. Most of that land has been bought and they already invested around $€ 423500$ in 2012 in Riemst alone. These investments clearly illustrate that the quarries are very valuable from an ecological point of view.

Individual benefits are also not taken into account in this analysis. Inhabitants of Riemst use the quarries to their own advantage. There is, for example, a bakery that makes its pies in the quarries, some farmers preserve their products in the quarries and there is still a mushroom grower active in Kanne and there is a family that connected its air conditioning system with the quarry underneath their house.

\section{Conclusions}

This study developed a methodology to assess the socio-economic impact of the presence and collapse of underground limestone quarries. The methodology is applied to a case study village (Riemst) in Belgium, but may be applied to other regions around the world facing problems of underground quarry collapses.

In Riemst, the presence and collapses of underground calcarenite limestone quarries have a significant socio-economic impact. For a period of 86 years, the direct and indirect damage related to sinkhole formations amounts to $€ 25400000$ ( $\pm € 5500000$ ) expressed in 2012 values. 45\% (around 11.5 million $€)$ of the economic damage can be attributed to the loss in real estate values. The direct damage is responsible for $29 \%$ ( $€ 7380000$ ) of the total damage and the preventive measures account for $26 \%$ 
( $€ 6500000$ ) of the total damage. The total yearly damage equals $€ 415000$ ( $\pm € 85000$ ) and here too almost half of it can be attributed to the depreciation of real estate ( $€ 230000)$.

The quarries also generate societal benefits. They have recreational, cultural-historical and ecological values. The yearly recreational value was at least $€ 613000$ in 2012 values. The tourist revenues are not taken into account so that the real recreational value is most probably even higher. The ecological and cultural-historical values augment to $€ 180000$ per year (in 2012 values). When a quarry collapses, part of the cultural-historical and ecological values will be lost. On average this corresponds with a forgone benefit of $€ 350$ per year.

Further, our study indicates that the gains from filling up the quarries below agricultural land are not economically profitable. For houses located above an underground limestone quarry it is also not economically profitable to fill up the quarries if one only looks at the direct costs and temporal likelihood of a sinkhole formation. However, if also the indirect costs - and particularly the real estate value losses - are taken into, then the benefits from preventive filling up the quarries outweigh the costs in the case study area. The net gain from filling up the underground quarry ranges $€ 38700$ to $€ 101700$ per house. This is only a lower bound of the net gain from filling up these underground quarries since preventive filling makes future collapses less likely so that future direct repair costs will also be smaller. As such our results clearly illustrate the need to take all types of costs and benefits into account if one wants to identify optimal mitigation strategies. This requires different types of data and valuation techniques and the methodology proposed in this paper can act as a guideline for other researchers and policy makers that aim to assess all sinkhole-related damage and perform a CBA in order to identify optimal mitigation strategies.

\section{Acknowledgement}

This research benefited from the input of interviewees of real estate agencies, notaries, public and private instances.

\section{References}

Argentieri, A., Carluccio, R. , Cecchini, F. , Chiappini, M. , Ciotoli, G. , De Ritis, R. , Di Filippo, M. , Di Nezza, M. Marchetti, M., Margottini, S. , Materni, V. , Meloni, F. , Nardi, A., Rotella, G., Sapia, V., Venuti, A. (2015). Early stage sinkhole formation in the Acque Albule basin of central Italy from geophysical and geochemical observations. Engineering Geology, 191: 36-47

Beerts, I., (2012). Report on visits of underground quarries in Kanne and Zichen-Bolder (Dutch). Tourist Office Riemst, 13/11/2012, ?pp.

Bodemrichtlijn.nl, Transport en overslag, kosten wegtransport. Online available on: http://www.bodemrichtlijn.nl/Bibliotheek/bodemsaneringstechnieken/c-grondverzet/c5transport-en-overslag/transport-en-overslag-kosten-wegtransport Website visited on 07/10/2013

Bosch, F.W., Felder, W.M., Gonggrijp, G.P. (1978). Ontdek het mergelland: Nederlandse landschappen, Hilversum, Instituut voor natuurbeschermingseducatie, 288p. 
Brinkmann, R., Parise, M., Dye, D. (2008).Sinkhole distribution in a rapidly developing urban environment: Hissborough County, Tampa Bay area, Florida. Engineering Geology, 99 (3-4), 169-184

Buttrick, D.B., van Schalkwyk, A., Kleywegt, R.J.,Watermeyer, R.B., (2001). Proposed method for dolomite land hazard and risk assessment in South Africa. Journal of South African Institution of Civil Engineering, 43, 27-36.

Buttrick, D.B., Trollip, N.Y.G.,Watermeyer, R.B., Pieterse, N.D., Gerber, A.A., (2011). A performance based approach to dolomite risk management. Environmental Earth Sciience, 64, 1127-1138.

Duchateau, P. (2013). Riemst, quarry supervisor Riemst, personal communication, internal reports of the municipality Riemst and digital files

Dusar, M., Lagrou, D., Willems, L., Felder, P.J., Matthijs, J. (2005). De mergelgrotten van Hinnisdael te vechmaal (gemeente Heers, Limburgs Haspengouw: een geologische bijdrage tot de studie van het Krijt. Koninklijk Belgisch Instituut voor natuurwetenschappen, geological survey of Belgium, 301, 89p.

Dusar, M., Lagrou, D., Dreesden, R. (2006), De mergelgrotten van Hinnisdael te vechmaal, geologisch erfgoed in de schaduw. Likona jaarboek 2006, 16, 6-13

Fedweb, Gebruik van uw auto, Online available on: http://minfin.fgov.be/portail2/nl/themes/transport/vehicles-use.htm\#G. Website visited on 07/10/2013

Galve, J. P., Bonachea, J., Remondo, J., Gutiérrez, F., Guerrero, J., Lucha, P., Sánchez, J. A. (2008). Development and validation of sinkhole susceptibility models in mantled karst settings. A case study from the Ebro valley evaporite karst (NE Spain). Engineering Geology, 99(3-4), 185-197. doi:10.1016/j.enggeo.2007.11.011

Galve, J.P., Gutiérrez, F., Guerrero, J., Alonso, J., Ignacio, D., (2012a). Optimizing the application of geogrids to roads in sinkhole-prone areas on the basis of hazard models and cost-benefit analyses. Geotextiles and Geomembranes. 34, 80-92.

Galve, J.P., Gutiérrez, F., Guerrero, J., Alonso, J., Ignacio, D., (2012b). Application of risk, cost- benefit and acceptability analyses to identify the most appropriate geogrid solution to mitigate sinkhole damage on roads. Engineering Geology, 145-146, 65-77.

Guerrero, J., Gutiérrez, F., Bonachea, J., \& Lucha, P. (2008). A sinkhole susceptibility zonation based on paleokarst analysis along a stretch of the Madrid-Barcelona high-speed railway built over gypsum- and salt-bearing evaporites (NE Spain). Engineering Geology, 102(1-2), 62-73. doi:10.1016/j.enggeo.2008.07.010

Gullentops, F., Wouters, L. (1996), Delfstoffen in Vlaanderen, Brussel, Ministerie van de Vlaamse Gemeenschap. Afdeling Natuurlijke Rijkdommen en Energie, 198p.

Gutiérrez, F., Guerrero, J., Lucha, P. (2008). Quantitative sinkhole hazard assessment. A case study from the Ebro Valley evaporate alluvial karst (NE Spain). Natural Hazards, 45, 211-233

Gutiérrez, F. , Parise, M., De Waele, J., Jourde H. (2014) A review on natural and human-induced geohazards and impacts in karst. Earth-Science Reviews, 138, 61-88

Jones, C.E., Blom, R.G. (2014) Bayou Corne, Louisiana, sinkhole: precursory deformation measured by radar interferometry. Geology, 42, :111-114

KNMI, monthly and yearly amount of precipitation in Maastricht, http://www.knmi.nl/klimatologie/maandgegevens/datafiles/mndgeg_380_rh24.txt. Website visited in 2013 
Markantonis V,Meyer V, Schwarze R. (2012). Valuating the intangible effects of natural hazardsreview and analysis of the costing methods. Natural Hazards and Earth System Science, 12, 1633-40.

Medaerts, V. (1998), De Roosburgramp eist 18 doden. Mergel, een zegen of een vloek?. Riemst, Medaerts, $144 \mathrm{p}$.

Medaerts, V. (2008), Roosburgramp 50 jaar later. Riemst, Medaerts, 157p.

Natuurhistorisch Museum (1981), Geologie en biologie van Zuid-Limburg, Maastricht, Natuurhistorisch Museum, 48p.

OC-GIS Vlaanderen (2013), Natura 2000 Vlaanderen, online available on: http://geovlaanderen.agiv.be/geo-vlaanderen/natura2000/

Ozdemir, A. (2015). Sinkhole Susceptibility Mapping Using a Frequency Ratio Method and GIS Technology Near Karapınar, Konya-Turkey. Procedia Earth and Planetary Science, 15,: 502506

Papathoma-Köhle M., Zischg A., Fuchs S., Glade T. \& Keiler M. (2015): Loss estimation for landslides in mountain areas - An integrated toolbox for vulnerability assessment and damage documentation. Environmental Modelling and Software 63, 156-169

Parise, M., 2012. A present risk from past activities: sinkhole occurrence above underground quarries. Carbonates Evaporites, 27(2) , 109-118.

Parise, M. and P. Lollino (2011). A preliminary analysis of failure mechanisms in karst and man-made underground caves in Southern Italy. Geomorphology, 134, 132-143

Parise,M., DeWaele, J., Gutiérrez, F., 2009. Current perspectives on the environmental impacts and hazards in karst. Environmental Geology 58 (2), 235-237.

Parise, M. , Closson, D., Gutiérrez, F., Stevanovic, Z. (2015). Anticipating and managing engineering problems in the complex karst environment. Environmental Earth Sciences, Forthcoming

Paukstys, B., Cooper, A.H., Arustiene, J., 1999. Planning for gypsumgeohazard in Lithuania and England. Engineering Geology. 52, 93-103.

Perman R, Ma Y, Common M, Maddisson D, McGilvray J. Natural resource and environmental economics. 4th ed. Edinburgh: Pearson Education Limited; 2011.

Romein, B.J. (1976), Ons krijtland Zuid-Limburg, geologische geschiedenis van Zuid-Limburg, Utrecht, Nederlandse geologische vereniging, vierde druk, 69p.

Sahu, P. , Lokhande, R.D. (2015) An Investigation of Sinkhole Subsidence and its Preventive Measures in Underground Coal Mining. Procedia Earth and Planetary Science, 11, 63-75.

Samyn, K., Mathieu, F. , Bitri, A. , Nachbaur, A., Closset, L. (2014). Integrated geophysical approach in assessing karst presence and sinkhole susceptibility along flood-protection dykes of the Loire River, Orléans, France. Engineering Geology, 183, 170-184

Schrevens, L., 29/07/2012, Yields agricultural crops. VLIF-vademecum SBB fiscal year 2012

Statbel households, number of households per municipality (situation 01/01/2011). Online available on:

http://www4.vlaanderen.be/sites/svr/cijfers/Exceltabellen/demografie/5_Huishoudens/2_G emeenten/1_Huishoudens_per_gemeente.xls Website visited on 15/11/2013

Statbel rent prices, Landbouw - Pachten in de landbouw (2002-2012). Online available on: http://statbel.fgov.be/nl/modules/publications/statistiques/economie/downloads/pachten.j $\mathrm{sp}$ 
Taheri, K., Gutiérrez, F., Mohseni, H., Raeisi, E., Taheri, M. (2015). Sinkhole susceptibility mapping using the analytical hierarchy process (AHP) and magnitude-frequency relationships: A case study in Hamadan province, Iran. Geomorphology, 234: 64-79

Van Den Eeckhaut, M. Poesen, J., Dusar, M., Martens, V., Duchateau, Ph. (2007), Sinkhole formation above underground limestone quarries: A case study in South Limburg (Belgium).

Geomorphology, 91, pp. 19-37

Vranken, L., Van Turnhout, P., Van Den Eeckhaut, M., Vandekerckhove, L., Poesen, J. (2013), Economic valuation of landslide damage in hilly regions: A case study from Flanders, Belgium. Science of the Total Environment, 447, pp. 323-336

Zêzere, J.L., Garcia R.A.C., Oliveira S.C., Reis E., 2008. Probabilistic landslide risk analysis considering direct costs in the area north of Lisbon (Portugal). Geomorphology, 94(3-4), pp. 467-495

Zhou W, Beck BF (2011) Engineering issues on karst. In: van Beynen P (ed) Karst Management. Springer, Dordrecht, pp 9-45 


\section{List of figures}
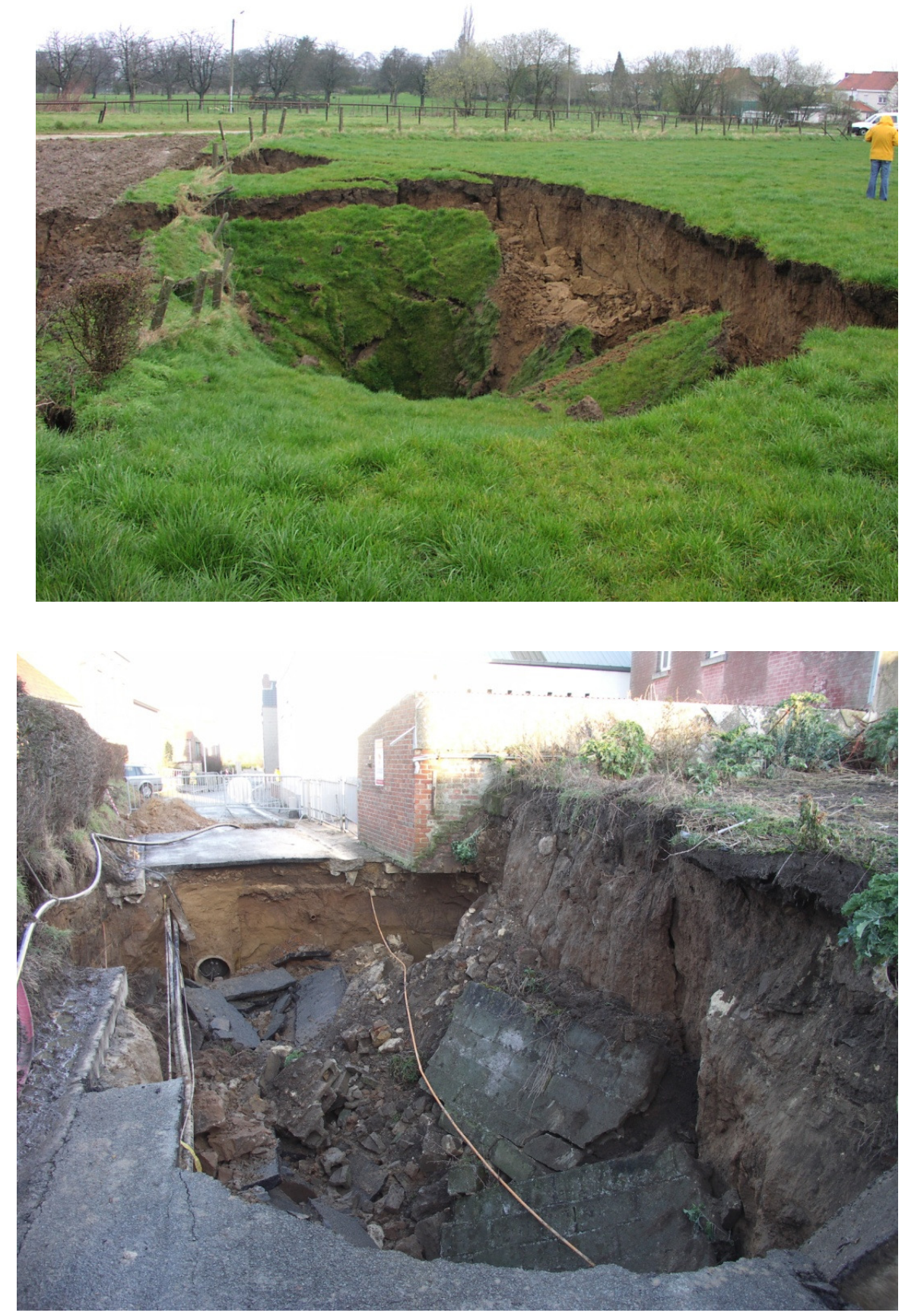

Fig. 1 Damage caused by sinkhole formation above underground limestone quarries in East Belgium. (A) damage to cropland (left) and pasture (right; Zussen, 20 March 2008, P. Duchateau). (B) damage to road and building (Val-Meer, 26 December 2009, J. Poesen). Both sinkholes are the result of fall of the overburden in galleries after local roof collapse, piping erosion in solution pipes or large-scale roof breakdown after pillar failures in a chain reaction (Van Den Eeckhaut et al. 2007). 


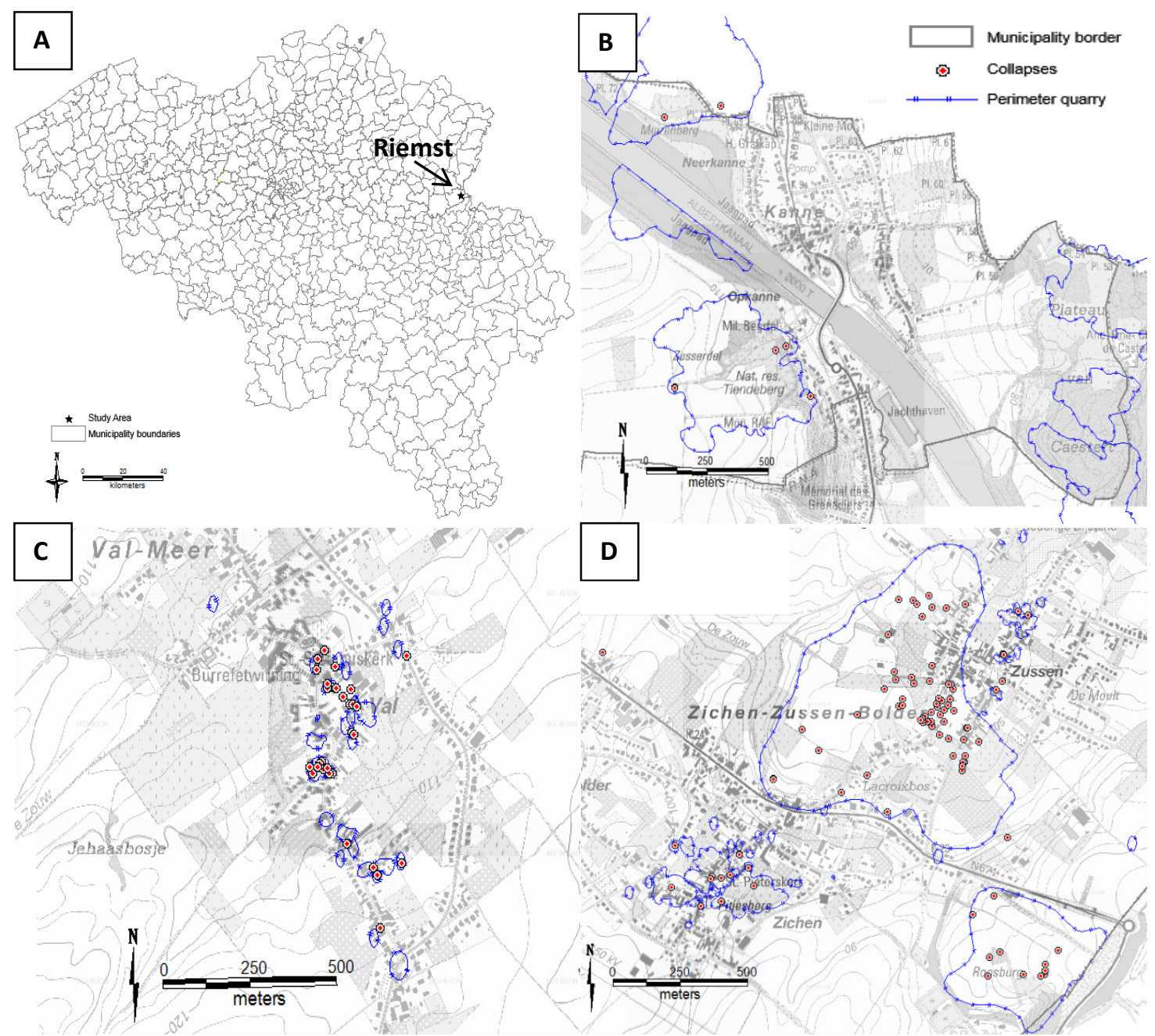

Figure 2. Location of the study area (Riemst) in Belgium (figure A), the location of the calcarenite limestone quarries (indicated by blue polygons) and collapses (sinkholes, indicated by red dots) in Kanne (figure B), Val-Meer (figure C) and Zichen-Zussen-Bolder (figure D) (source: Duchateau, 2012;). B, C and D are projected on a topographic map (๔ 2012 NGI Topomapviewer). 


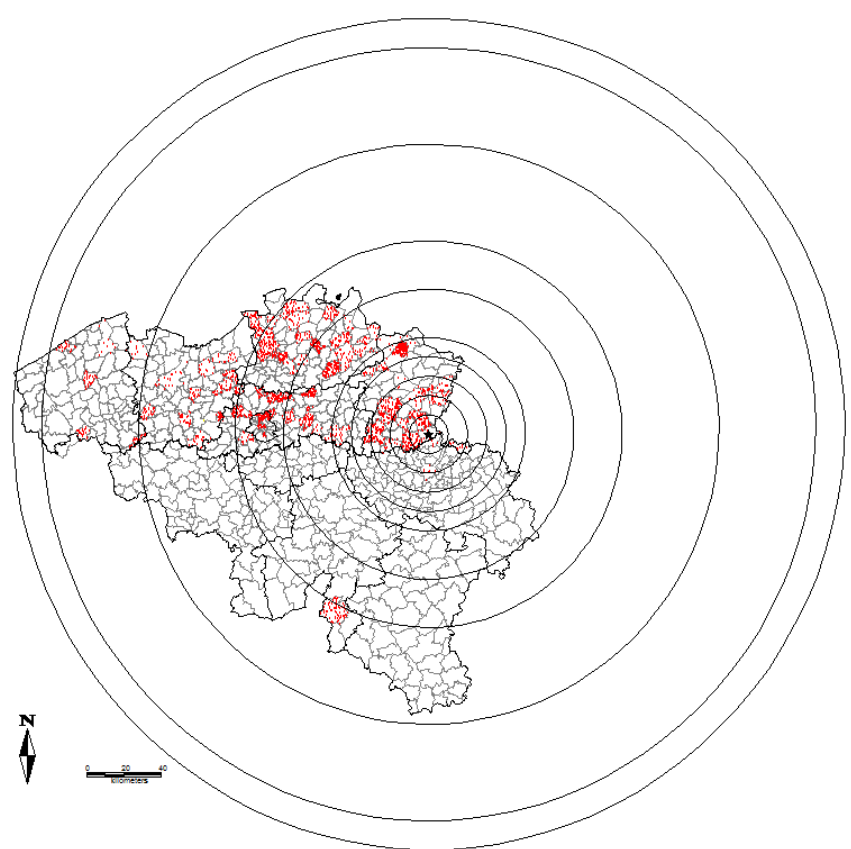

Figure 3. Home location of the tourists visiting the underground quarries in Riemst in Belgim in 2012. The circular zones are used for the travel cost method. One dot represents ten tourists (source data: Beerts, 2012)

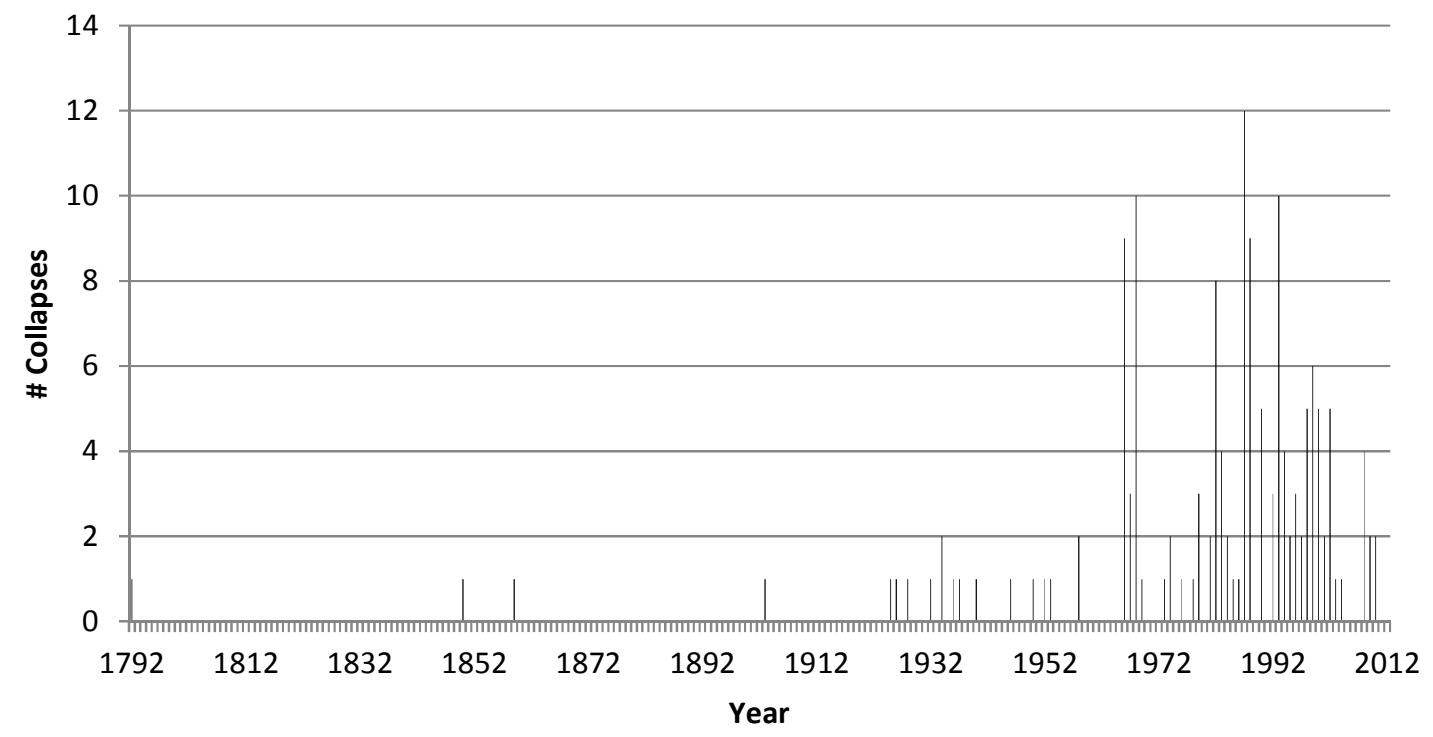

Figure 4. The evolution of the reported number of sinkholes $(n=151)$ formed above underground calcarenite limestone quarries in Riemst between 1792 and 2012 (source: Duchateau, 2013; Van Den Eeckhaut et al, 2007;) 


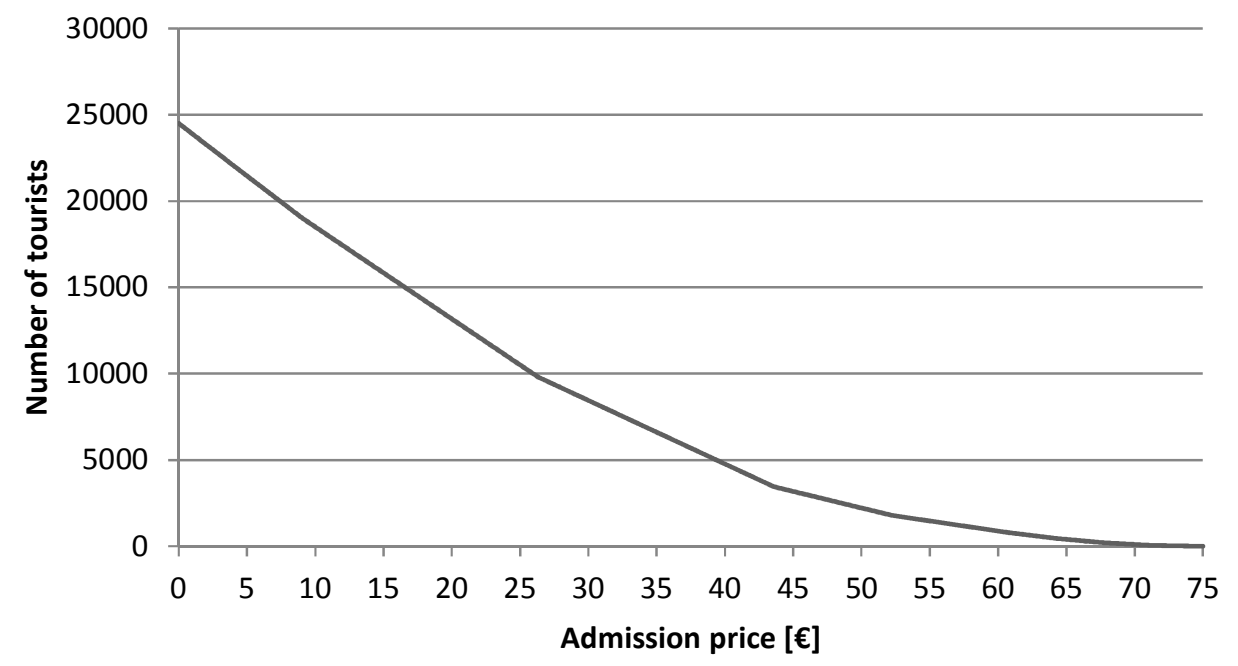

Figure 5. Number of tourists visiting the underground quarries in Riemst as a function of the potential admission price (source: Beerts, 2012)

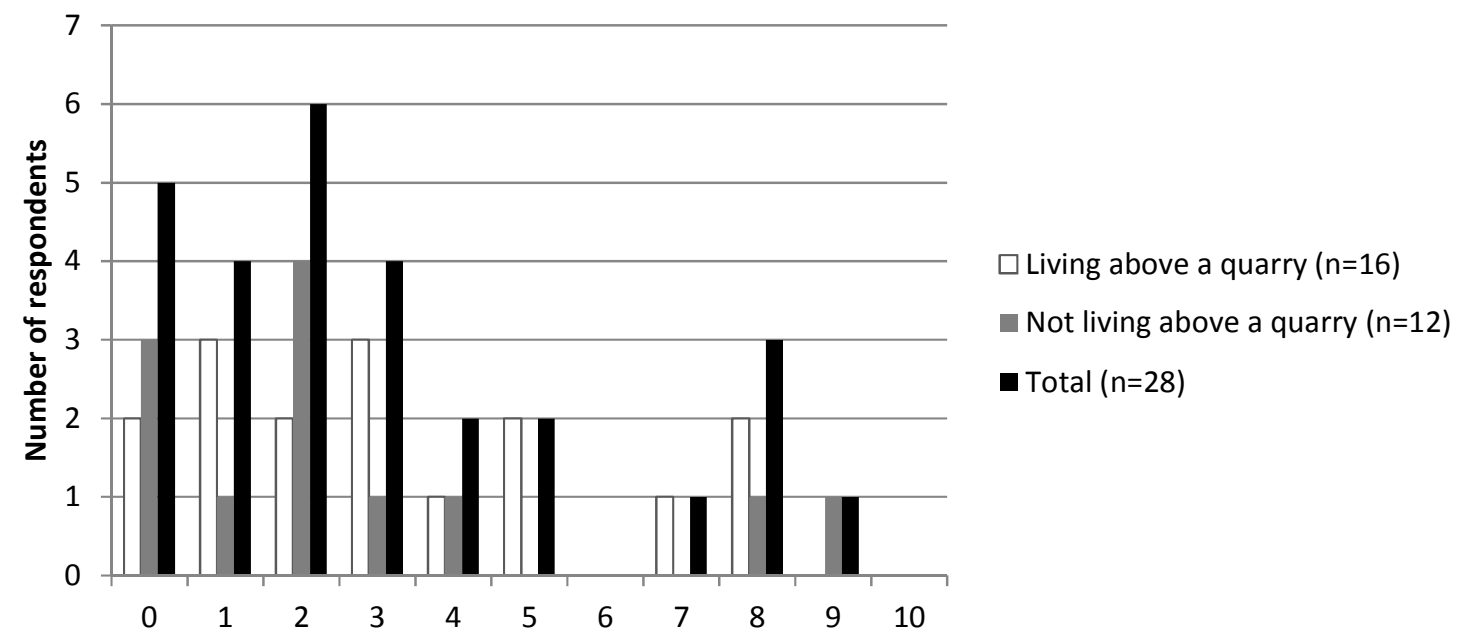

Figure 6. Assessment of the danger, perceived by the inhabitants of the affected municipalities, linked to the presence of underground quarries based on a 10 point likert scale: $0=$ no danger at all, $10=$ very large danger 


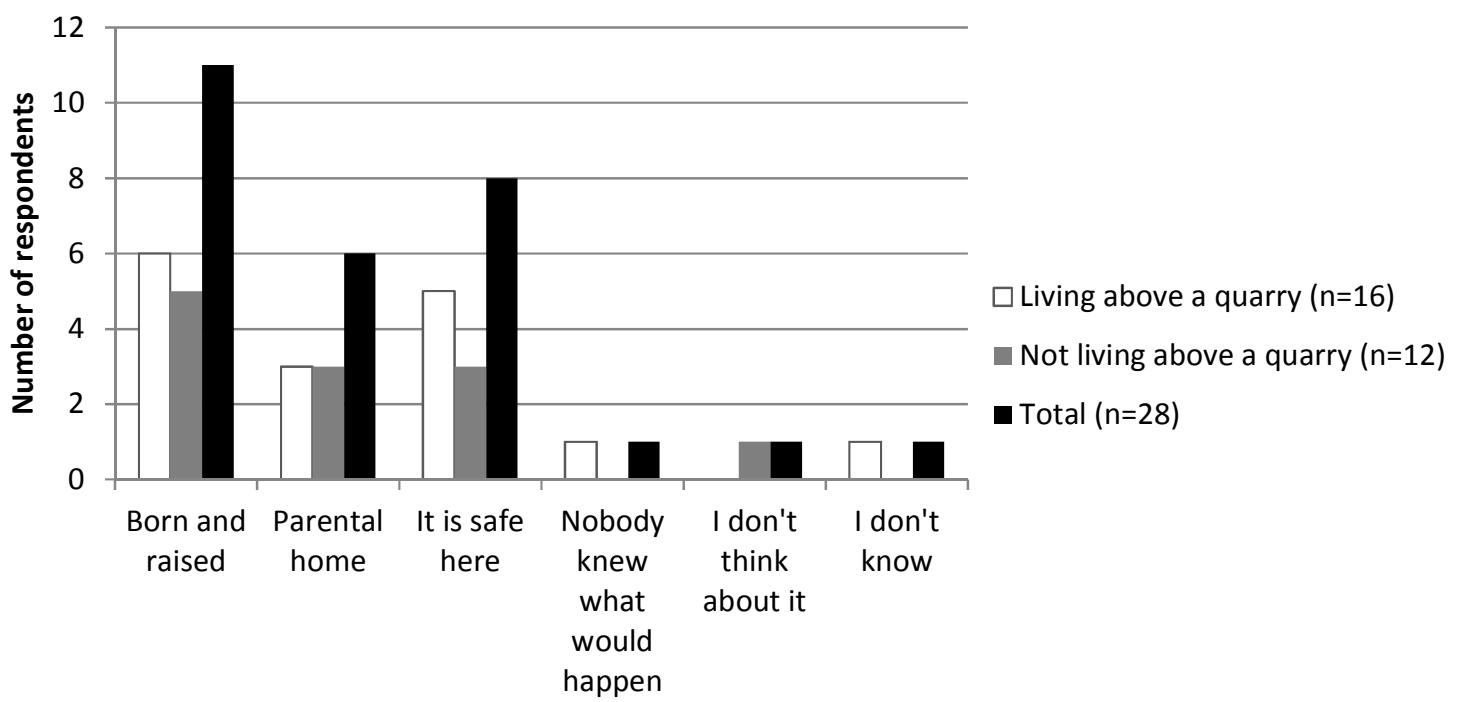

Figure 7. Reasons for inhabitants of Riemst to live nearby or above a quarry 


\section{List of tables}

Table 1. Unit prices for the repair cost of utility lines and the reconstruction of roads (source: Vranken, 2013)

\begin{tabular}{lrc}
\hline UTILITY LINES & Price in 2012 & \\
\hline Subsidence of gas pipe & 5143 & $€$ /collapse \\
Damage to electricity poles & 1626 & $€ /$ collapse \\
Crack in water mains & 2139 & $€$ /collapse \\
Subsidence of water pipe & 19542 & $€ /$ collapse \\
Subsidence of sewage pipe & 10476 & $€ /$ collapse \\
Reconstruction of roads & 46.55 & $€ / \mathrm{m}^{2}$ \\
\hline
\end{tabular}

Table 2. Scenarios used to assess the depreciation of real estate values due to their location above an underground limestone quarry in a survey among real estate agents and notaries

\begin{tabular}{lll}
\hline Scenario & Description & $\begin{array}{l}\text { Value } \\
\text { loss }\end{array}$ \\
\hline Reference & Not situated above a quarry. The reference situation & $0 \%$ \\
\hline Scenario 1 & Situated above a quarry, but the quarry has been completely filled up below the house & $2 \%$ \\
\hline Scenario 2 & $\begin{array}{l}\text { Situated above a quarry and not filled in below the house. But there has never been a case of } \\
\text { sinkhole formation or subsidence on the property }\end{array}$ & $7 \%$ \\
\hline Scenario 3 & $\begin{array}{l}\text { Situated above a quarry that is not filled up below the house. There has been a case of } \\
\text { sinkhole formation or subsidence on the property in the past }\end{array}$ & $55 \%$ \\
\hline
\end{tabular}

Table 3. Real estate value losses of houses due to their location above an underground limestone quarry in the municipality Riemst for the different scenarios

\begin{tabular}{|c|c|c|c|c|}
\hline & \multirow{2}{*}{$\begin{array}{l}\text { Number of } \\
\text { houses }\end{array}$} & \multicolumn{3}{|c|}{ Value loss $(€)$} \\
\hline & & Average $^{a}$ & Minimum $^{\mathrm{a}}$ & Maximum $^{a}$ \\
\hline Scenario $1+2$ & 367 & 3550725 & 1578100 & 5523350 \\
\hline Scenario 3 & 67 & 8066800 & 8066800 & 8066800 \\
\hline Total value loss & 434 & 11617525 & 9644900 & 13590150 \\
\hline
\end{tabular}

${ }^{a}$ Average, minimum and maximum value loss if one assumes that the value of all houses under scenario $1+2$ decreases respectively with $4.5 \%, 2 \%$ and $7 \%$. For houses under scenario 3, the value loss equals 55\%. Average house price in 2012 is $€ 215000$. 
Table 4. Total economic damage due to the presence of underground limestone quarries in the municipality Riemst, Belgium (total area Riemst: $58 \mathbf{~ k m}^{2}$, quarry area: $200 \mathrm{ha}$ ). Minimum, maximum and average value of different types of damage for the period 1926-2012. All costs and losses are expressed as 2012 values.

\begin{tabular}{lrrr}
\hline & & & \\
& Minimum [€] & Maximum [€] & Average [€] \\
\hline DIRECT DAMAGE & & & \\
\hline Cost to fill up sinkholes & 2161734 & 8794095 & 5477916 \\
Repair cost - private properties & 1454507 & 1532499 & 1493503 \\
Repair cost - public properties & 321179 & 493497 & 407338 \\
& & & \\
\hline INDIRECT DAMAGE & & & 11617525 \\
\hline Real estate value losses & 9644900 & 13590150 & 1133 \\
Production losses & 476 & 1789 & 869785 \\
Prevention costs: working cost volunteers + wage quarry manager & 758030 & 981540 & 116441 \\
Prevention costs- monitoring systems & 116441 & 116441 \\
Prevention costs - preventive filling of quarries & 5547499 & 5547499 & 5547499 \\
& & & \\
\hline TOTAL DAMAGE & $€ 19860716$ & $€ 30913460$ & $€ 25387090$ \\
\hline
\end{tabular}

Table 5. Yearly societal benefits of the limestone quarries in Riemst, Belgium. All benefits are expressed in 2012 values.

\begin{tabular}{lr}
\hline BENEFITS FOR BELGIUM & Benefits in $€$ \\
\hline Recreational value & 593824 \\
\hline BENEFITS ONLY FOR RIEMST & \\
\hline Cultural- historical value & 64334 \\
Ecological value & 115228 \\
\hline
\end{tabular}

Table 6. Overview of the forgone societal benefits due to sinkhole formation in the municipality Riemst. Benefits are expressed in 2012 values.

\begin{tabular}{lr|r|r|r}
\hline & $\begin{array}{r}\text { Benefits per unit } \\
\text { of quarry volume } \\
{\left[€ / \mathrm{m}^{3}\right]}\end{array}$ & $\begin{array}{r}\text { Average forgone benefits } \\
\text { per collapse }{ }^{\text {a }}[€ / \text { collapse] }\end{array}$ & $\begin{array}{r}\text { Average forgone benefits } \\
\text { per year }{ }^{\text {a }}[€ / \text { year] }\end{array}$ \\
\hline Cultural-historical value & 64334 & 117 & 126 \\
Ecological value & 115228 & 0,01 & 209 & 226 \\
\hline Total yearly forgone benefits & & 0,02 & & $\mathbf{3 5 2}$ \\
\hline
\end{tabular}

a The average collapsed volume of a sinkhole is $10891 \mathrm{~m}^{3}$ and there were on average 1.1 sinkhole formations per year over the period 1926-2012 
Table 7. Overview of the economic damage due to the presence of underground quarries in Riemst, expressed in 2012 values

\begin{tabular}{|c|c|c|c|c|}
\hline & Period & $\begin{array}{r}\text { Cost/ } \\
\text { estimated value loss } \\
\operatorname{Min}-\operatorname{Max}(€) \\
\end{array}$ & $\begin{array}{r}\text { Annual cost/ } \\
\text { estimated value loss } \\
\text { Min - Max ( } € / \text { year) }\end{array}$ & $\begin{array}{r}\text { Average annual cost/ } \\
\text { estimated value loss } \\
(€ / \text { year) }\end{array}$ \\
\hline \multicolumn{5}{|l|}{ DIRECT DAMAGE } \\
\hline Filling up cost & 86 years & $2161734-8794095$ & $25136-102257$ & 63697 \\
\hline Repair cost - private properties & 86 years & $1454507-1532499$ & $16913-17820$ & 17366 \\
\hline Repair cost - public properties & 86 years & $321179-493497$ & $3735-5738$ & 4736 \\
\hline TOTAL YEARLY DIRECT DAMAGE & & & & $€ 85800$ \\
\hline \multicolumn{5}{|l|}{ INDIRECT DAMAGE } \\
\hline Real estate value losses & Life time (50 years) & $9644900-13590150$ & $190017-268922$ & 229470 \\
\hline Production losses & 86 years & $476-1133$ & $6-21$ & 13 \\
\hline Prevention costs: working cost volunteers + wage quarry manager & 35 years & $758030-981540$ & $21658-28044$ & 24851 \\
\hline Prevention costs (measuring systems) & 11 years & 116441 & 10586 & 10586 \\
\hline Prevention costs (preventive filling in) & 86 years & 5547499 & 64506 & 64506 \\
\hline TOTAL YEARLY INDIRECT DAMAGE & & & & $€ 329426$ \\
\hline TOTAL YEARLY DAMAGE & & & & $€ 415266$ \\
\hline
\end{tabular}

